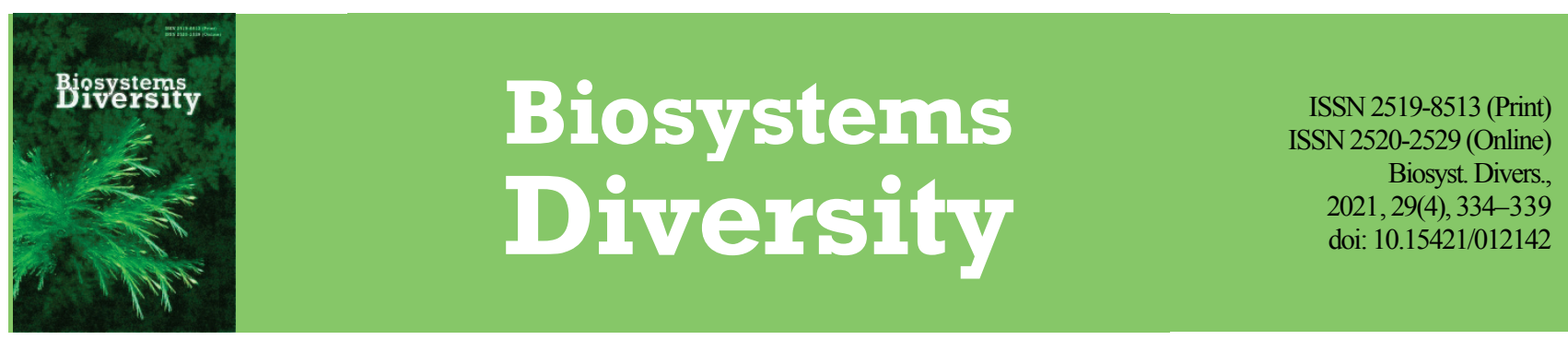

\title{
Soluble cuticular wax composition and antimicrobial activity of the fruits of Chaenomeles species and an interspecific hybrid
}

\author{
Y. V. Lykholat*, N. O. Khromykh*, O. O. Didur*, S. I. Okovytyy*, \\ T. V. Sklyar*, V. R. Davydov*, T. Y. Lykholat*, I. M. Kovalenko** \\ * Oles Honchar Dnipro National University, Dnipro, Ukraine \\ **Sumy National Agricultural University, Sumy, Ukraine
}

Article info

Received 03.10.2021

Received in revised form 28.10 .2021

Accepted 29.10.2021

Oles Honchar Dnipro

National University

Gagarin av., 72,

Diipro, 49010, Ukraine.

Tel.:+38-050-487-87-17.

E-mail:khromykhn@ukr.net

Sumy National Agricultural

University, Kondratyeva st.

160/5, Sumy, 40021, Ukraine

Tel.:+38-099-525-61-82.

E-mail:

kovalenko_977@ukr.net
Lykholat, Y. V., Khromykh, N. O., Didur, O. O., Okovytyy, S. I., Sklyar, T. V., Davydov, V. R., Lykholat, T. Y., \& Kovalenko, I. M. (2021). Soluble cuticular wax composition and antimicrobial activity of the fruits of Chaenomeles species and an interspecific hybrid. Biosystems Diversity, 29(4), 334-339. doi:10.15421/012142

Plants of the genus Chaenomeles Lindl. (Rosaceae) naturally grow in Southeast Asia and represent the richest resource of biologically active compounds with beneficial properties for humans. Plants of $C$. japonica (Thunb.) Lindl. and C. speciosa (Sweet) Nakai species, and interspecific hybrid $C . \times$ superba $($ Frahm) Rehder $(C$. japonica $\times$ C. speciosa, Superba group $)$ have been successfully introduced in the steppe zone of Ukraine and bear fruits. In this study, we evaluated chemical composition of fruit cuticular waxes and antimicrobial activity of fruit extracts. The soluble waxes were characterized using gas chromatography-mass spectrometry (GC-MS), and 26-36 compounds, representing $91.7-96.6 \%$ of the total soluble cuticular waxes, were identified. Waxes of Chaenomeles fruits belonged to six classes, namely fatty acids, alcohols, aldehydes, esters, ethers and alkanes. Aldehydes 7-hexadecenal and heptacosanal, and alkanes hexatriacontane and tetrapentacontane were the main constituents in the soluble cuticular waxes of $C$. speciosa and $C . \times$ superba fruits, accounting for more than half of the total contents. However, alkane tetrapentacontane, alcohol 8,10-hexadecadien-1-ol and heptacosanal prevailed in C. japonica fruit waxes. Isopropanolic fruit extracts exhibited dose-dependent antimicrobial activity against four Gramnegative bacteria, five Gram-positive bacteria and one fungal strain in the disc diffusion assay. In general, extracts from the Chaenomeles fruits demonstrated higher activity against Gram+ bacteria than Gram- strains. The strongest inhibiting activity was shown against Staphylococcus epidermidis (by the fruit extracts of $C . \times$ superba and $C$. speciosa), Micrococcus lysodeikticus and Candida albicans (both by $C$. $\times$ superba fruit extract). Results of the study confirmed accumulation of the bioactive compounds in the fruit waxes of different Chaenomeles species and antimicrobial ability of Chaenomeles fruits as well. These findings revealed the bioactive compounds in fruit cuticular waxes and suggested health-promoting properties of introduced Chaenomeles species.

Keywords: Chaenomeles japonica; Chaenomeles speciosa; Chaenomeles $\times$ superba; fruits; cuticular wax; fatty acids; aldehydes; alkanes; antimicrobial ability.

\section{Introduction}

Genus Chaenomeles Lindley (Rosaceae) consist of five species originated in Southern-East Asia, namely $C$. speciosa, C. sinensis, and C. thibetica which are the endemics in China, and C. cathayensis and C.japonica (Yang et al., 2015). Health-promoting abilities of Chaenomeles plants have long been known and used in traditional medicine to treat various diseases, such as rheumatism, cholera, dysentery, enteritis, beriberi and vitamin C deficiency syndrome (Zhang et al., 2014). In recent years, pharmacological assays of $C$. speciosa have confirmed multifaceted properties, including anti-inflammatory, antinociceptive, antimicrobial, antioxidant, immunoregulatory, antiparkinsonian, hepatoprotective and antitumour effects. Analysis of chemical composition of essential oils from $C$. speciosa dried fruits carried out by Xianfei et al. (2007) led to identification of $\alpha$-terpineol, $\beta$-caryophyllene, terpinen-4-ol and 1,8cineole as the main constituents. Miao et al. (2016) represented two common Chaenomeles fruits in China (C. speciosa and C. sinensis) as a rich resource of phenolic acids (vanillic, gallic, chlorogenic, ferulic and $\mathrm{p}$ coumaric acids), triterpenes (oleanolic and ursolic acids), flavonoids (rutin, catechin and epicatechin) and other compounds contributing to high antioxidant capacity of Chaenomeles fruits.

The incredible variety of useful properties of the Chaenomeles plants has made them an attractive object for introduction in various regions (Rumpunen, 2002). In particular, cultivation of $C$. japonica is gaining popularity in northern European countries, especially in the Baltic Sea area. Kikowska et al. (2019) reported the development of protocol for C. japonica micropropagation with a confirmation of genome size stability of the in vitro-propagated plantlets and the high acclimatization rate. Urbanaviciute et al. (2020) tested different extraction conditions for the fruits of the new Japanese quince (C. japonica) cultivars by studying variability of phenolic compounds and free radical scavenging activity of plant extracts, in which isoquercitrin, rutin, $(+)$-catechin, $(-)$-epicatechin, and chlorogenic acid were identified. The leaf extracts of the same C. japonica new cultivars can efficiently reduce glioblastoma cell viability while preserving non-cancerous cells, and are worth further investigations as potential anticancer drugs (Zvikas et al., 2021).

In Ukraine, those plants with beneficial properties have not yet received proper attention and distribution, occupying an extremely small area of plantations (Moskalets et al., 2019). In the steppe zone, several Chaenomeles species and interspecific hybrids have been successfully introduced, and they bear fruits (Lykholat et al., 2019) and demonstrate the ability to accumulate the phenolic compounds. However, abundance and composition of the bioactive compounds in Chaenomeles fruits greatly depend on the growth conditions. Zheng et al. (2018) revealed significant differences in chemical composition and antioxidant activity of $C$. specios $a$ dried fruits from four production areas in China. Great variability both of total polyphenol content and the main bioactive compounds content were determined in the fresh fruits of five wild Chaenomeles species, namely $C$. japonica, $C$. sinensis, $C$. speciosa, $C$. cathayensis and $C$. thibetica (Du et al., 2013). The successful introduction of the Chaenomeles 
plants in the steppe zone is largely due to the cuticle waxes, which create a protective barrier against environmental stresses and, in turn, are also affected by various environmental factors (Xue et al., 2017). The cuticular waxes contribute to the protection against insects (Rebora et al., 2020) and pathogens (Łaźniewska et al., 2012), as well as to fruit development and ripening (Trivedi et al., 2019). Despite the important role of wax in plant vitality (Lykholat et al., 2018), chemical composition of the cuticular waxes of Chaenomeles fruits is poorly studied. In addition, the ability of introduced plants to accumulate bioactive compounds and retain beneficial properties in a new environment has not been sufficiently observed. The aim of this work was to clarify the specific features of fruit cuticular waxes and antimicrobial activity of Chaenomeles plants from different regions of origin, adapted to the conditions of the steppe zone.

\section{Materials and methods}

Fruits of the Chaenomeles plants were taken from the Botanical Garden of Oles Honchar Dnipro National University (48 $26^{\prime} 07^{\prime \prime}$ N, $35^{\circ} 02^{\prime} 34^{\prime \prime}$ E, Dnipro city, Ukraine). There, several plants of the genus Chaenomeles Lindl. Were introduced more than 25 years ago in the steppe climate with low precipitation ( $473 \mathrm{~mm}$ average, but $265 \mathrm{~mm}$ in dry years) and sharp temperature changes. Ripe fruits of $C$. japonica (Thunb.) Lindl., C. speciosa (Sweet) Nakai, and C. $\times$ superba $($ Frahm) Rehder $(C$. japoni$c a \times C$. speciosa, Superba group) were collected in the first half of September 2021, packed in plastic containers and delivered to the laboratory immediately. The soluble cuticular waxes from the surface of Chaenomeles fruits were extracted with chloroform (Chloroform Pharm, Ukraine) according to Buschhaus et al. (2007) by immersing the fruit in a solvent for 60 seconds, followed by solvent evaporation in $40{ }^{\circ} \mathrm{C}$ using rotary evaporator (IKA ${ }^{\circledR}$ RV 10, Germany). Obtained solid fraction was stored in $4^{\circ} \mathrm{C}$; for GC-MS analysis, dry residue was dissolved in chloroform and filtered through a syringe filter.

Chloroformic extracts were subjected to gas chromatography - mass spectrometry (GC-MS) analysis using Shimadzu GCMS-QP 2020 El equipped with $\mathrm{Rxi}^{\mathrm{B}}-5 \mathrm{~ms}$ column $(30 \mathrm{~m} \times 0.25 \mathrm{~mm}$, film thickness $0.25 \mu \mathrm{m}$ ) containing $5 \%$ diphenyl $/ 95 \%$ dimethyl polysiloxane as a fixed liquid phase. The column temperature was $50^{\circ} \mathrm{C}$, with $5 \mathrm{~min}$ initial hold, and then the programmed temperature gradient was increased to $300^{\circ} \mathrm{C}$ at the rate of $15{ }^{\circ} \mathrm{C}$ per min, and kept constant in $300^{\circ} \mathrm{C}$ for $10.5 \mathrm{~min}$. The carrier gas helium passed at the flow rate of $54 \mathrm{~mL} / \mathrm{min}$. Injector temperature was $300^{\circ} \mathrm{C}$; sample volume was $1 \mu \mathrm{L}$. Mass Spectrum Library 2014 for GC-MS (O2125401310) was used to identify the separated compounds by comparing the mass spectra obtained with those stored in the library database (National Institute of Standards and Technology library similarity index, NIST14.lib, NIST14s.lib). The content of individual compounds of cuticular waxes was estimated according to the area of the corresponding peak and expressed as a percentage of the total.
Plant extracts for biological assays were prepared using $80 \%$ isopropanol (INEOS, Germany). Then, $2.0 \mathrm{~g}$ weighed portion of fresh fruit (peel and flesh) was triturated with $20 \mathrm{~mL}$ of isopropanol and kept for 24 hours at room temperature in dark with occasional shaking. Then, the extracts were filtered through the paper filters and dried at $45^{\circ} \mathrm{C}$ using rotary evaporator IKA ${ }^{\circledR}$ RV 10 (Germany). For bioassays, solid residue was dissolved in isopropanol.

Antibacterial activity of isopropanolic extracts of Chaenomeles fruits was determined by the disc diffusion method (Bhimba et al., 2012). Test cultures of microorganisms were taken from the culture collection of Microbiology, Virology and Biotechnology Department of Oles Honchar Dnipro National University. Four Gram-negative bacteria, namely Erwinia dissolvens (strain 170), Escherichia coli (strain B 906), Pseudomonas aeruginosa, Klebsiella pneumoniae, and five Gram-positive bacteria, namely Micrococcus lysodeikticus, Staphylococcus aureus (strain B 904), S. aureus (strain B 209), S. epidermidis (strain ATCC 149), S. epidermidis (strain 919), and diploid fungus Candida albicans were tested. Petri plates containing MPA medium (Meat Peptone Agar RM1049 HiMedia Laboratories Pvt. Limited, India) were inoculated with $10^{9} \mathrm{CFU}$ (colony forming units) suspension of microorganisms. Sterile paper discs $(6 \mathrm{~mm}$ diameter) were impregnated with $10 \mu \mathrm{L}$ of crude isopropanolic fruit extracts and placed on the agar surface, followed by incubation at $37{ }^{\circ} \mathrm{C}$ for $24 \mathrm{~h}$. Ofloxacin ( $5.0 \mu \mathrm{g}$ per disc) was used as the positive control in all cases. Inhibition zones produced by plant fruit extracts around the discs were measured along with disc diameter, and antibacterial activity was expressed as the diameter of the inhibition zone (mm). Photographs of Petri plates were taken using a camera Canon IXUS 185 Silver (Japan).

All bioassays were carried out in triplicate. Statistical processing of the experimental results was based on the analysis of variance (ANOVA). The obtained data were expressed as the mean \pm standard deviation $(\mathrm{x} \pm$ $\mathrm{SD}$ ), and the differences between the means were tested with Tukey's HSD. All differences were considered to be statistically significant at $\mathrm{P}<0.05$.

\section{Results}

Gas chromatography - mass spectrometry assays showed a similar distribution of phytochemicals on the chromatograms of chloroformic extracts of the soluble cuticular waxes from the fruits of three different Chaenomeles species (Fig. 1). The study of phytochemicals carried out by GCMS analysis of chloroformic extracts revealed a total of 53 compounds in fruit waxes, particularly 36 components in C. japonica, 26 in C. speciosa and 29 components in $C$. $\times$ superba soluble waxes (Table 1).

The compounds of fruit cuticular waxes of all studied plant species were classified into six chemical classes, namely fatty acids, aldehydes, alcohols, alkanes, esters, and ethers. Results of GC-MS identification showed different distribution of different chemical classes in the fruit cuticular wax of Chaenomeles species (Fig. 2).

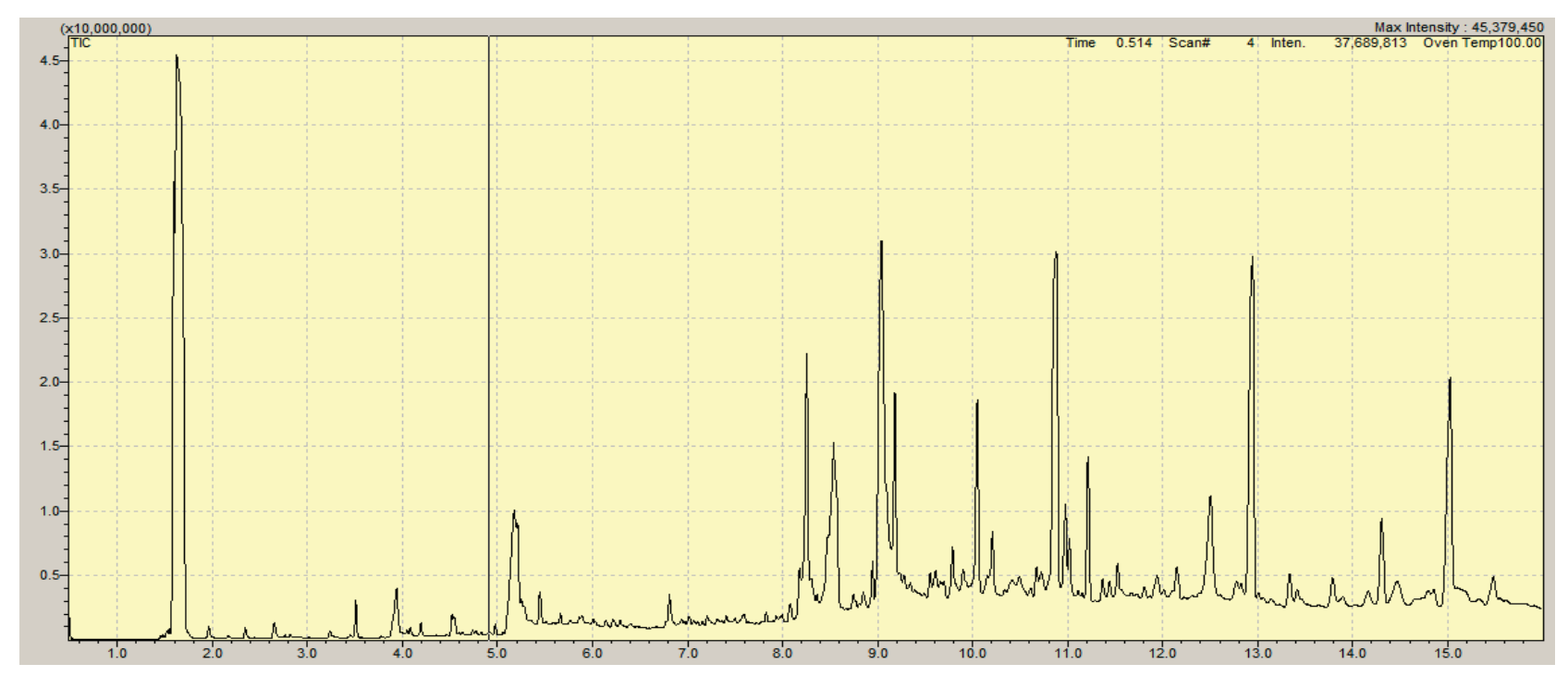

Fig. 1. GC-MS chromatogram showing the components of the soluble cuticular waxes from Chaenomeles fruits 


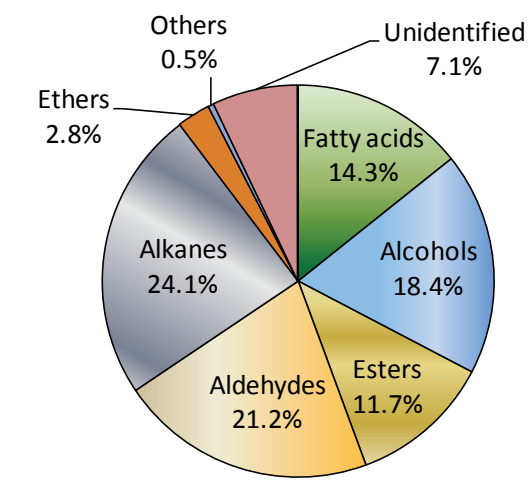

$a$

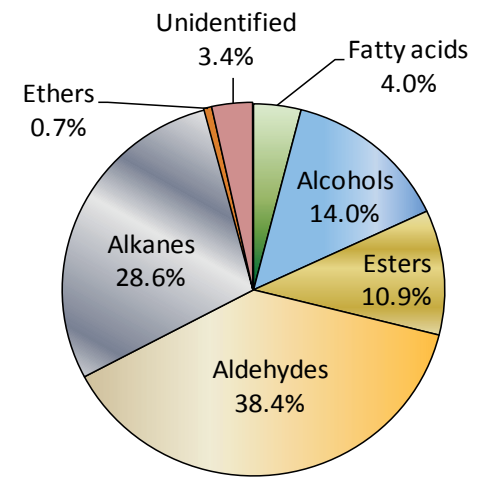

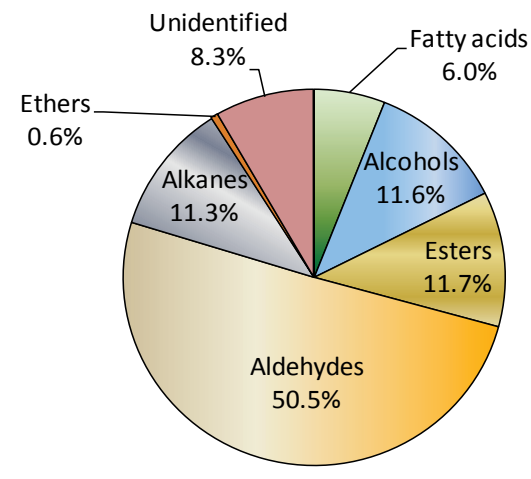

C

Fig. 2. Relative content ( $\%$ of total) of different chemical classes in soluble cuticular wax of Chaenomeles fruits:

$$
a-C \text {.japonica, } b-C \text {. speciosa, } c-C . \times \text { superba }
$$

Fraction of fatty acids in the fruit cuticular waxes consisted of 12 compounds with an even and odd number of carbon atoms in the range $\mathrm{C}_{6}-\mathrm{C}_{25}$. The greatest content of fatty acids and their diversity was found in the soluble cuticular waxes of $C$. japonica fruits $(14.27 \%$ of total amount of the compound was represented by nine different fatty acids). Share of long-chain fatty acids $\left(\mathrm{C}_{16}\right.$ and more $)$ was the largest in C.japonica fruit waxes (10.62\% of total amount of the compound compared with $3.61 \%$ in $C$. speciosa fruits and $4.97 \%$ in $C . \times$ superba fruits), with dominating hexadecanoic acid in waxes of all species.

The most abundant alcohol fraction was found in C. japonica cuticular waxes, consisting of primary (seven compounds in the range $\mathrm{C}_{10}$ $\mathrm{C}_{41}$ ), secondary (two compounds), and tertiary alcohols (one compound), but the latter were not identified in the waxes of two other species. Share of primary alcohols was the highest in all fruit waxes and reached $17.32 \%$ in C. japonica, $13.29 \%$ in C. speciosa and $9.58 \%$ in C. $\times$ superba. Among the primary alcohols, 1 -hentetracontanol prevailed in the cuticular waxes of $C$. specios $a$ and $C$. $\times$ superba fruits, while the highest content of 8,10-hexadien-1-ol was in C. japonica waxes.

Aldehydes in the fruit cuticular waxes were represented by 18 compounds with an even and odd carbons number in the range $\mathrm{C}_{7}-\mathrm{C}_{60}$. The geeatest amount of long-chain aldehydes was identified in the cuticular waxes of $C$. $\times$ superba fruits (49.22\% of total amount versus $19.97 \%$ in C. japonica and $37.69 \%$ in C. speciosa fruits). Heptacosanal was the main compound in the aldehydes fraction of all fruit waxes; however, only cuticular waxes of $C$. speciosa and $C . \times$ superba fruits contained the significant amount of hexadecenal.

The alkane's fraction in the soluble cuticular waxes of Chaenomeles fruits consisted of three long-chain compounds $\left(\mathrm{C}_{27}-\mathrm{C}_{54}\right)$ dominated by hexatriacontane in C. speciosa, and tetrapentacontane in C. japonica and C. speciosa fruits.

The fraction of fatty acid esters was represented by six different compounds with an even and odd carbons number in the range $C_{10}-C_{25}$. Among them, diisooctyl phthalate content was the highest in the fruit cuticular waxes of all species. The content of another fatty acid esters was the highest in C. speciosa fruit waxes (2.80\% of total amount compared with $1.29 \%$ in $C$. speciosa and $1.35 \%$ in $C . \times$ superba fruits).

In the fruit cuticular waxes of all species, the ethers content was the lowest, representing only three long-chain compounds $\left(\mathrm{C}_{25}-\mathrm{C}_{35}\right)$, which in total accounted for $2.77 \%$ of $C$. japonica fruits. Overall content of primary alcohols and esters was $29.03 \%$ in the cuticular waxes of $C$. japonica fruits, $24.15 \%$ in C. speciosa fruit waxes and $21.24 \%$ in C. $\times$ superba fruits. Aldehydes and alkanes in total accounted for $44.07 \%$ in fruit waxes of C. japonica, $66.31 \%$ in C. speciosa fruits, and $60.51 \%$ in C. $\times$ superba fruit waxes.

Results of the disc diffusion assay showed bioactivity of the isopropanolic extracts of all Chaenomeles fruits. Bacteriostatic and fungistatic effects on the tested strains varied depending on plant species and extract concentration (Table 2).

Table 1

Components of chloroform extracts of the Chaenomeles fruit cuticular waxes as identified by GC-MS assay

\begin{tabular}{|c|c|c|c|c|c|}
\hline \multirow{2}{*}{ Compound name } & \multirow{2}{*}{ Formula } & \multirow{2}{*}{$\mathrm{RT}, \min$} & \multicolumn{3}{|c|}{ Peak area, $\%$} \\
\hline & & & C.japonica & C. speciosa & C. $\times$ superba \\
\hline $\begin{array}{l}\text { Heptanal } \\
\end{array}$ & $\mathrm{C}_{7} \mathrm{H}_{14} \mathrm{O}$ & 2.349 & 0.13 & 0.10 & 0.17 \\
\hline Hexanoic acid (syn. Caproic acid) & $\mathrm{C}_{6} \mathrm{H}_{12} \mathrm{O}_{2}$ & 2.662 & 0.19 & - & - \\
\hline Octanoic acid (syn. Caprylic acid) & $\mathrm{C}_{8} \mathrm{H}_{16} \mathrm{O}_{2}$ & 2.683 & - & 0.12 & 0.22 \\
\hline Octanal & $\mathrm{C}_{8} \mathrm{H}_{16} \mathrm{O}$ & 2.880 & - & - & 0.07 \\
\hline Nonanal & $\mathrm{C}_{9} \mathrm{H}_{18} \mathrm{O}$ & 3.418 & - & 0.26 & 0.44 \\
\hline 3,7-Dimethyl-1,6-octadien-3-ol (syn. Linalool) & $\mathrm{C}_{10} \mathrm{H}_{18} \mathrm{O}$ & 3.488 & 0.35 & - & - \\
\hline Benzoic acid & $\mathrm{C}_{7} \mathrm{H}_{6} \mathrm{O}_{2}$ & 4.044 & 2.15 & - & - \\
\hline Octanoic acid, ethyl ester & $\mathrm{C}_{10} \mathrm{H}_{20} \mathrm{O}_{2}$ & 4.091 & - & 0.08 & - \\
\hline 2-Decenal & $\mathrm{C}_{10} \mathrm{H}_{18} \mathrm{O}$ & 4.255 & 0.26 & - & - \\
\hline Nonanoic acid (syn. Pelargonic acid) & $\mathrm{C}_{9} \mathrm{H}_{18} \mathrm{O}_{2}$ & 4.376 & 0.17 & 0.28 & 0.31 \\
\hline 3-Decyn-2-ol & $\mathrm{C}_{10} \mathrm{H}_{18} \mathrm{O}$ & 4.524 & 0.16 & - & - \\
\hline Undecanoic acid & $\mathrm{C}_{11} \mathrm{H}_{22} \mathrm{O}_{2}$ & 4.659 & - & - & 0.16 \\
\hline 2H-1-Benzopyran (syn. 2H-Chromene) & $\mathrm{C}_{9} \mathrm{H}_{8} \mathrm{O}$ & 4.975 & 0.48 & - & - \\
\hline 9-Decenoic acid & $\mathrm{C}_{10} \mathrm{H}_{18} \mathrm{O}_{2}$ & 5.134 & 0.78 & - & 0.32 \\
\hline 2,6-Octadiene-1,8-diol (syn. Hydroxynerol) & $\mathrm{C}_{10} \mathrm{H}_{18} \mathrm{O}_{2}$ & 5.351 & 0.19 & - & 0.06 \\
\hline 3-Phenylprop-2-enal (syn. Cinnamaldehyde) & $\mathrm{C}_{9} \mathrm{H}_{8} \mathrm{O}$ & 5.467 & - & - & 0.59 \\
\hline 2-Propenoic acid, 3-phenyl (syn. Cinnamic acid) & $\mathrm{C}_{9} \mathrm{H}_{8} \mathrm{O}_{2}$ & 5.646 & 0.36 & - & - \\
\hline Benzaldehyde-4(1-methylethyl) & $\mathrm{C}_{10} \mathrm{H}_{12} \mathrm{O}$ & 6.957 & 0.23 & - & - \\
\hline 1-Heptatriacontanol & $\mathrm{C}_{31} \mathrm{H}_{64} \mathrm{O}$ & 7,019 & 0.21 & 0.32 & 0.29 \\
\hline 10,12-Pentacosactiynoic acid & $\mathrm{C}_{25} \mathrm{H}_{42} \mathrm{O}_{2}$ & 7.200 & 0.14 & - & - \\
\hline 9-Tetradecanal (syn. Myristylaldehyde) & $\mathrm{C}_{14} \mathrm{H}_{26} \mathrm{O}$ & 7.560 & - & 0.10 & - \\
\hline 1-Pentadecanal & $\mathrm{C}_{15} \mathrm{H}_{30} \mathrm{O}$ & 7.596 & 0.61 & - & - \\
\hline Hexadecanal & $\mathrm{C}_{16} \mathrm{H}_{32} \mathrm{O}$ & 7.612 & 1.89 & - & 1.86 \\
\hline 1-Hexadecanol & $\mathrm{C}_{16} \mathrm{H}_{34} \mathrm{O}$ & 7.900 & - & - & 0.34 \\
\hline 9-Tetradecenal & $\mathrm{C}_{14} \mathrm{H}_{26} \mathrm{O}$ & 8.107 & - & 0.20 & - \\
\hline
\end{tabular}




\begin{tabular}{|c|c|c|c|c|c|}
\hline \multirow{2}{*}{ Compound name } & \multirow{2}{*}{ Formula } & \multirow{2}{*}{$\mathrm{RT}$, min } & \multicolumn{3}{|c|}{ Peak area, \% } \\
\hline & & & C. japonica & C. speciosa & C. $\times$ superba \\
\hline cis-10-Heptadecenoic acid & $\mathrm{C}_{17} \mathrm{H}_{32} \mathrm{O}_{2}$ & 8.173 & - & - & 0.44 \\
\hline Octadec-9-enoic acid (syn. Oleic acid) & $\mathrm{C}_{18} \mathrm{H}_{34} \mathrm{O}_{2}$ & 8.191 & 0.53 & - & - \\
\hline Hexadecanoic acid (syn. Palmitic acid) & $\mathrm{C}_{16} \mathrm{H}_{32} \mathrm{O}_{2}$ & 8.268 & 7.97 & 3.61 & 4.38 \\
\hline Hexadecanoic acid, ethyl ester & $\mathrm{C}_{18} \mathrm{H}_{36} \mathrm{O}_{2}$ & 8.358 & 0.68 & - & - \\
\hline 8,10-Hexadecadien-1-ol & $\mathrm{C}_{16} \mathrm{H}_{30} \mathrm{O}$ & 8.456 & 15.48 & - & 0.36 \\
\hline 7-Hexadecenal & $\mathrm{C}_{16} \mathrm{H}_{30} \mathrm{O}_{2}$ & 8.846 & 0.90 & 12.31 & 20.83 \\
\hline 8-Hexadecenal-14-Methyl & $\mathrm{C}_{17} \mathrm{H}_{32} \mathrm{O}$ & 8.957 & - & 0.12 & - \\
\hline 9,12-Octadecadienoic acid (syn. Linoleic acid) & $\mathrm{C}_{18} \mathrm{H}_{32} \mathrm{O}_{2}$ & 9.089 & 1.98 & - & 0.15 \\
\hline Ethyl-9-octadec-9-enoate (syn. Ethyl oleate) & $\mathrm{C}_{20} \mathrm{H}_{38} \mathrm{O}_{2}$ & 9.123 & 0.27 & - & - \\
\hline Undec-10-ynoic acid, tetradecyl ester & $\mathrm{C}_{25} \mathrm{H}_{46} \mathrm{O}_{2}$ & 9.463 & - & 1.21 & 1.35 \\
\hline Benzenpropanoic acid, 4-pentadecyl ester & $\mathrm{C}_{23} \mathrm{H}_{38} \mathrm{O}_{2}$ & 9.822 & 1.85 & - & - \\
\hline Hexadecyl nonyl ether & $\mathrm{C}_{25} \mathrm{H}_{52} \mathrm{O}$ & 10.027 & 0.81 & 0.69 & 0.62 \\
\hline Eicosanal & $\mathrm{C}_{20} \mathrm{H}_{40} \mathrm{O}$ & 10.128 & - & 1.56 & - \\
\hline Henicosanal & $\mathrm{C}_{21} \mathrm{H}_{42} \mathrm{O}$ & 10.200 & 2.97 & 3.84 & 1.77 \\
\hline 1,3,12-Nonadecatriene-5,14-diol & $\mathrm{C}_{19} \mathrm{H}_{34} \mathrm{O}_{2}$ & 10.216 & 0.54 & 0.75 & 1.97 \\
\hline Diisooctyl phthalate & $\mathrm{C}_{24} \mathrm{H}_{38} \mathrm{O}_{4}$ & 10.874 & 8.91 & 9.57 & 10.31 \\
\hline Hexacosanal & $\mathrm{C}_{26} \mathrm{H}_{52} \mathrm{O}$ & 10.935 & - & 1.15 & - \\
\hline 1-Heptacosanol & $\mathrm{C}_{27} \mathrm{H}_{56} \mathrm{O}$ & 12.135 & - & 3.19 & 2.26 \\
\hline Eicosyl nonyl ether & $\mathrm{C}_{29} \mathrm{H}_{60} \mathrm{O}$ & 12.179 & 1.20 & - & - \\
\hline Tricosanal & $\mathrm{C}_{23} \mathrm{H}_{46} \mathrm{O}$ & 12.488 & 1.86 & 2.32 & 0.54 \\
\hline Octacosanol & $\mathrm{C}_{28} \mathrm{H}_{58} \mathrm{O}$ & 12.812 & 1.47 & 0.68 & 0.95 \\
\hline 2-Methylhexacosane & $\mathrm{C}_{27} \mathrm{H}_{56}$ & 13.842 & 0.67 & 3.01 & - \\
\hline Heptacosanal & $\mathrm{C}_{27} \mathrm{H}_{54} \mathrm{O}$ & 14.138 & 10.47 & 16.39 & 23.04 \\
\hline Hexatriacontane & $\mathrm{C}_{36} \mathrm{H}_{74}$ & 14.226 & - & 23.74 & - \\
\hline Hexacosyl nonyl ether & $\mathrm{C}_{35} \mathrm{H}_{72} \mathrm{O}$ & 14.821 & 0.76 & - & - \\
\hline Tetrapentacontane & $\mathrm{C}_{54} \mathrm{H}_{110}$ & 14.912 & 23.43 & 1.87 & 11.29 \\
\hline 1-Hentetracontanol & $\mathrm{C}_{41} \mathrm{H}_{84} \mathrm{O}$ & 15.048 & - & 9.10 & 5.38 \\
\hline Triacosanal & $\mathrm{C}_{60} \mathrm{H}_{30} \mathrm{O}$ & 15.457 & 1.88 & - & 1.18 \\
\hline Total, $\%$ & & & 92.93 & 96.57 & 91.65 \\
\hline Unidentified, \% & & & 7.07 & 3.43 & 8.35 \\
\hline
\end{tabular}

Note: RT - retention time; data on compounds content are expressed as peak area ( $\%$ of the total).

Table 2

Diameter of inhibition zone ( $\mathrm{mm}$ ) of the Chaenomeles fruits isopropanolic extracts

\begin{tabular}{|c|c|c|c|c|c|c|c|}
\hline \multirow{2}{*}{ Test-culture } & \multicolumn{2}{|c|}{ C. japonica extracts } & \multicolumn{2}{|c|}{ C. speciosa extracts } & C. $\times$ superba extracts & \multicolumn{2}{|c|}{ Ofloxacin } \\
\hline & $235.0 \mu \mathrm{g} / \mu \mathrm{L}$ & $45.0 \mu \mathrm{g} / \mu \mathrm{L}$ & $235.0 \mu \mathrm{g} / \mu \mathrm{L}$ & $45.0 \mu \mathrm{g} / \mu \mathrm{L}$ & $235.0 \mu \mathrm{g} / \mu \mathrm{L}$ & $45.0 \mu \mathrm{g} / \mu \mathrm{L}$ & $5.0 \mu \mathrm{g} / \mathrm{disc}$ \\
\hline E. dissolvens & $11.67 \pm 0.31^{\mathrm{a}}$ & $11.33 \pm 0.35^{\text {ah }}$ & $18.01 \pm 0.26^{\mathrm{a}}$ & $11.13 \pm 0.21^{\mathrm{a}}$ & $16.73 \pm 0.49^{\mathrm{abc}}$ & $14.13 \pm 0.47^{\mathrm{ab}}$ & $30.17 \pm 0.55^{\mathrm{a}}$ \\
\hline E. coli & $18.47 \pm 1.45^{\mathrm{b}}$ & $14.67 \pm 0.59^{b}$ & $15.57 \pm 0.35^{\mathrm{b}}$ & $13.50 \pm 0.51^{\mathrm{b}}$ & $17.03 \pm 0.42^{\mathrm{adf}}$ & $13.57 \pm 0.51^{\mathrm{a}}$ & $30.13 \pm 0.65^{\mathrm{a}}$ \\
\hline P. aeruginosa & $13.17 \pm 0.15^{\mathrm{c}}$ & $10.60 \pm 0.56^{\mathrm{ac}}$ & $9.53 \pm 0.25^{\mathrm{c}}$ & $9.23 \pm 0.35^{\mathrm{c}}$ & $17.67 \pm 0.15^{\mathrm{ae}}$ & $10.47 \pm 0.25^{\mathrm{c}}$ & $21.4 \pm 0.44^{\mathrm{b}}$ \\
\hline M. lysodeikticus & $15.30 \pm 0.10^{\mathrm{d}}$ & $14.23 \pm 0.25^{\mathrm{bd}}$ & $14.70 \pm 0.20^{\mathrm{d}}$ & $9.97 \pm 0.21^{\mathrm{c}}$ & $21.53 \pm 0.40^{\mathrm{g}}$ & $11.40 \pm 0.20^{\mathrm{de}}$ & $19.27 \pm 0.25^{\mathrm{c}}$ \\
\hline K. pneumoniae & $14.90 \pm 0.36^{\mathrm{def}}$ & $6.53 \pm 0.06^{\mathrm{g}}$ & $16.20 \pm 0.30^{\mathrm{be}}$ & $13.03 \pm 0.12^{\mathrm{b}}$ & $16.13 \pm 0.31^{\mathrm{bf}}$ & $10.90 \pm 0.36^{\text {dff }}$ & $27.90 \pm 0.44^{\mathrm{d}}$ \\
\hline S. aureus B904 & $17.02 \pm 0.17^{\mathrm{bg}}$ & $15.23 \pm 0.25^{\mathrm{b}}$ & $16.87 \pm 0.15^{\mathrm{e}}$ & $14.67 \pm 0.42^{\mathrm{d}}$ & $12.47 \pm 0.15^{\mathrm{h}}$ & $7.37 \pm 0.06^{\mathrm{g}}$ & $26.63 \pm 0.31^{\mathrm{d}}$ \\
\hline S. aureus B209 & $13.60 \pm 0.17^{\mathrm{e}}$ & $13.07 \pm 0.25^{\mathrm{ef}}$ & $18.87 \pm 0.15^{\mathrm{f}}$ & $15.53 \pm 0.42^{\text {de }}$ & $14.30 \pm 0.60^{\mathrm{i}}$ & $11.43 \pm 0.45^{\mathrm{ef}}$ & $25.03 \pm 0.51^{\mathrm{e}}$ \\
\hline S. epidermidis ATCC149 & $15.93 \pm 0.25^{\mathrm{dg}}$ & $13.6 \pm 0.26^{\mathrm{de}}$ & $19.03 \pm 0.12^{\mathrm{g}}$ & $15.83 \pm 0.21^{\mathrm{e}}$ & $17.67 \pm 0.21^{\text {ode }}$ & $14.01 \pm 0.26^{\mathrm{a}}$ & $23.63 \pm 0.12^{f}$ \\
\hline S. epidermidis B919 & $13.77 \pm 0.31^{\mathrm{cef}}$ & $10.23 \pm 0.15^{\mathrm{c}}$ & $29.60 \pm 0.17^{\mathrm{h}}$ & $19.43 \pm 0.25^{\mathrm{f}}$ & $33.33 \pm 0.15^{j}$ & $16.30 \pm 0.26^{\mathrm{h}}$ & $32.20 \pm 0.56^{\mathrm{g}}$ \\
\hline C. albicans & $15.10 \pm 0.20^{\mathrm{df}}$ & $12.23 \pm 0.20^{\text {fh }}$ & $18.43 \pm 0.15^{\mathrm{af}}$ & $11.17 \pm 0.25^{\mathrm{ag}}$ & $19.93 \pm 0.06^{\mathrm{k}}$ & $14.93 \pm 0.25^{\mathrm{b}}$ & NA \\
\hline
\end{tabular}

Note: * - the diameter of the inhibition zones ( $\mathrm{mm})$, including the disc diameter $(6 \mathrm{~mm})$, are given as mean $\pm \mathrm{SD}$ of triplicate experiments; values with different superscripts in each column are significantly different according to Tukey's test $(\mathrm{P}<0.05)$; NA - no activity.

The isopropanolic extracts of $C$. japonica fruits exerted more significant bacteriostatic effects on the tested Gram-positive bacterial strains, especially Micrococcus lysodeikticus, Staphylococcus aureus B904, and $S$. epidermidis ATCC149; at the same time, bacterial strains $S$. aureus B209 and S. epidermidis B919 were relatively more resistant. As with the Gram-negative bacteria, the extract of $C$. japonica fruits demonstrated lower activity, except a significant effect on Escherichia coli B906 strain. Activity of the extracts from $C$. speciosa fruits was the strongest against Gram+ bacteria, such as all tested $S$. aureus and $S$. epidermidis strains, especially against $S$. epidermidis B919. Among Gram-negative bacterial strains, Erwinia dissolvens and Klebsiella pneumoniae strains were the most susceptible to the action of the $C$. speciosa fruit extracts. The extracts from $C . \times$ superba fruits exhibited the strongest activity against Gram+ bacteria Micrococcus lysodeikticus and both $S$. epidermidis tested strains, namely S. epidermidis ATCC149 and S. epidermidis B919. As for the Gram-negative bacteria, the extract of $C$. $\times$ superba fruits showed significant activity against all the tested strains, especially against Escherichia coli and Pseudomonas aeruginosa. With regard to the fungal strain Candida albicans, the fruit extracts of all plant species demonstrated notable effects with the highest activity of $C$. $\times$ superb $a$ and $C$. speciosa extracts.

In general, isopropanolic extracts of the tested Chaenomeles fruits demonstrated higher activity against the strains of Gram-positive bacteria than Gram-negative strains. Isopropanolic extracts of $C$. japonica fruits showed the greatest activity against $E$. coli (inhibition zone diameter $18.5 \mathrm{~mm}$ ) and $S$. aureus B904 $(17.0 \mathrm{~mm})$. Extracts of $C$. speciosa fruits were most active against $E$. dissolvens (diameter $18.0 \mathrm{~mm}$ ), $K$. pneumoniae $(16.2 \mathrm{~mm})$, S. aureus B209 (18.8 mm) and S. epidermidis ATCC149 $(19.0 \mathrm{~mm})$. Extracts of $C . \times$ superba fruits demonstrated the highest activity against $P$. aeruginosa (inhibition zone diameter $17.7 \mathrm{~mm}$ ), M. lysodeikticus $(21.5 \mathrm{~mm})$, S. epidermidis B919 $(33.3 \mathrm{~mm})$, and C. albicans (19.9 mm).

\section{Discussion}

The constituents of soluble fruit cuticular waxes of introduced Chaenomeles species, namely $C$. japonica, $C$. speciosa, and interspecific hybrid $C$. $\times$ superba were classified into six chemical classes ; fatty acids, aldehydes, alcohols, alkanes, esters, and ethers. Similarly, fatty acids and alkanes were identified as the most abundant components in mandarin fruit epicuticular waxes (Ding et al., 2020). The fruit cuticular waxes of the studied Chaenomeles species demonstrated the notable differences in compound composition. Waxes of the C. japonica fruits were observed to have the highest amounts of individual components and long-chain fatty acids, as well as the most abundant fractions of alcohols (in the range of 
$\left.\mathrm{C}_{16}-\mathrm{C}_{28}\right)$ and esters $\left(\mathrm{C}_{18}-\mathrm{C}_{25}\right)$ as compared to two other species. In the fruit waxes of $C$. speciosa, the highest content of alkanes $\left(\mathrm{C}_{27}-\mathrm{C}_{54}\right)$ was found, while aldehydes fraction $\left(\mathrm{C}_{16}-\mathrm{C}_{60}\right)$ was the largest in the waxes of $C$. $\times$ superba fruits. Similar differences in the compositions of fruit waxes were found between 35 pear cultivars belonging to five different species and hybrid interspecies (Wu et al., 2018), as well as between the melting and non-melting peach varieties (Belge et al., 2014). In general, the obtained results are consistent with the known data (Trivedi et al., 2019) that the chemical compositions of fruit cuticular waxes vary greatly between fruit species and are modified by the developmental and environmental cues affecting the protective properties of the wax. Prunus cultivars are dominated by n-alkanes with even and odd numbers of carbons in the range from $\mathrm{C}_{27}$ to $\mathrm{C}_{60}$ (Lykholat et al., 2021). Many studies have shown that alkanes are predominant in epicuticular wax on many fruits (Rios et al., 2015; Wu et al., 2018), and accumulation of very long chain alkanes on the surface of fruit peel may be induced by low temperature (Hao et al., 2017) or water deficit (Kosma et al., 2009). Prevalence of n-alkanes in the cuticular waxes can be explained by the assumption of Fernández et al. (2016) that the non-polar compounds with low solubility, such as alkanes, can migrate from the cell wall to the epicuticular wax layer, while the polar compounds (i.e. alcohols, acids, esters) will be held in the waxes' inner layer. However, this pattern was not seen in the cuticular waxes of the Chaenomeles fruits, and alkanes (2-methylhexacosane $\mathrm{C}_{27}$ and tetrapentacontane $\mathrm{C}_{54}$ ) accounted for the greatest share in the fruit waxes of C. japonica only, while the aldehydes' fraction was the largest in both C. speciosa and $C . \times$ superba fruit waxes.

The peculiarities of the Chaenomeles fruit waxes' composition correlate with the reported regularities and can be explained on the basis of the processes of biosynthesis of wax components. It is known that cuticular wax is produced from the biosynthetic pathway that has two main branches, including acyl reduction and decarbonylation of $\mathrm{C}_{16}$ and $\mathrm{C}_{18}$ fatty acids (Xue et al., 2017). In the acyl reduction branch, primary alcohols are produced by reduction of very long chain fatty acid precursors. These fatty alcohols can be further combined with fatty acid to produce wax esters. In the other branch, aldehydes are produced from very long chain fatty acid precursors, followed by aldehyde decarbonylation to produce alkanes. Since aldehydes are the direct precursors of alkanes and determine their formation, it is likely that the dominance of alkanes in the fruit waxes can be found in a certain period during Chaenomeles fruit ripening. Taking into account the differences in the rates of fruit ripening of the introduced Chaenomeles species, it can be assumed that the cuticular waxes of the $C$. japonica fruits were formed faster than $C$. specios $a$ and $C . \times$ super$b a$ fruit waxes. However, despite the differences in the maturation rate, the biosynthesis of Chaenomeles fruit waxes apparently occurs along the same path. The total amount of fatty aldehydes and alkanes exceeds the sum of primary alcohols and fatty esters (45.3\% compared with $29.0 \%$ ) in the waxes of $C$. japonica fruits, indicating predominance of the decarbonylation pathway. More significant overweight of total amount of aldehydes and alkanes over the total amount of primary alcohols and ethers was found in C. speciosa fruit cuticular waxes (67.0\% against $24.2 \%)$ and C. $\times$ superba fruit waxes $(61.8 \%$ against $21.2 \%)$. The findings confirm the well-known opinion (Martin \& Rose, 2014; Wang et al., 2014) that the composition, structure, and architecture of fruit cuticles show considerable variability among varieties, species, and also throughout the development. The structure and biosynthesis pathway of fruit waxes do not necessarily coincide with the waxes of other plant parts, including leaf waxes, in which acyl reduction may be the main branch for wax biosynthesis (Tomasi et al., 2018).

In our study, isopropanolic fruit extracts of $C$. japonica, $C$. $\times$ superba and $C$. speciosa inhibited growth of all tested strains, confirming antimicrobial activity of Chaenomeles species. In particular, a broad spectrum of antibacterial activity was shown by the essential oil extracted from the dried C. speciosa fruits (Xianfei et al., 2007). All extracts of Chaenomeles fruit were more active against Gram-positive than Gram-negative bacteria. The most resistant bacterial strains were: Erwinia dissolvens against the extracts of $C$. japonica fruits, Pseudomonas aeruginosa against the C. speciosa extracts, and Klebsiella pneumonia against the fruit extracts of $C$. $\times$ superba. At the same time, these strains were susceptible to the action of the fruit extracts from another species: Erwinia dissolvens was inhibited by extracts of $C$. $\times$ superba and $C$. speciosa, Pseudomonas aeruginosa - by $C$. $\times$ superba extracts, and Klebsiella pneumonia - by C. speciosa extracts. Similar differences in the antimicrobial activity were found between the fruit extracts of three $C$. japonica cultivars, which also were more active against Gram+ bacteria, as reported by Urbanaviciute et al. (2020). The authors attributed the differences found only to the polyphenols content in fruit extracts. Without questioning the important role of phenolic compounds in the antimicrobial activity of fruits, we also paid attention to the soluble cuticular waxes components which must be present in whole fruit extracts. For example, cinnamaldehyde was represented as a new antibacterial agent that has been shown to have substantial antimicrobial activity, as well as an array of other medicinal properties (Ashakirin et al., 2017; Doyle \& Stephens, 2019). Linoleic and oleic acids are well-known as bioactive compounds with versatile health benefits, including antibacterial activity (Dilika et al., 2000), antifungal activities against plant pathogenic fungi (Walters et al., 2004), and cancer prevention (Diab et al., 2021). Moreover, Zheng et al. (2005) demonstrated that antibacterial activities of long-chain unsaturated fatty acids, such as linoleic acid, palmitoleic acid, oleic acid, linolenic acid, and arachidonic acid are mediated by the inhibition of bacterial fatty acid synthesis. Hexadecanoic acid, hexadecanoic acid ethyl ester, (E)-9-octadecenoic acid ethyl ester, and octadecanoic acid ethyl ester, which were identified in the hexanic extract from Manilkara subsericea fruits, exhibited antimicrobial activity against $S$. aureus ATCC25923 (Fernandes et al., 2013). Diisooctyl phthalate found in the cuticular wax extract of the Chaenomeles fruit is suspected to have bioactivity similar to dibutyl phthalate and mono(2ethylhexyl) phthalate in fungal filtrates, which exhibited a wide spectrum of antibacterial activity (Bhimba et al., 2012), or di(2-ethylhexyl) phthalate, which exhibited activity against Candida albicans fungus and the Gram-positive bacteria Sarcina lutea (Lotfy et al., 2018). As for the Candida albicans, all isopropanolic extracts of the Chaenomeles fruits had notable fungistatic activity, contrasting with the data of Urbanaviciute et al. (2020) where none of the extracts of three $C$. japonica cultivars exerted antifungal activity against $C a n d i d a$ albicans yeast.

\section{Conclusion}

Fruits of all three introduced Chaenomeles species (C. japonica, C. speciosa, and $C . \times$ superba) have a rich component composition of the soluble cuticular waxes, and showed the substantial antimicrobial activity against all the selected strains. The detectable amounts of linoleic acid, oleic acid, hexadecanoic acid, hexadecanoic acid ethyl ester and cinnamaldehyde, well-known as bioactive compounds with versatile health benefits, were found in the soluble waxes of the fruits. Bacteriostatic and fungistatic effects of the fruit extracts of all Chaenomeles species against four Gram-negative and five Gram-positive bacteria and one fungal strain varied both between different concentrations of extracts and microbial strains. The findings not only confirmed the well-known versatile health benefits of Chaenomeles fruits, but also indicated the implementation of these useful properties by the introduced plants in unfavourable climatic conditions. The studied Chaenomeles species can be recommended for broad distribution in the steppe zone and introduction into agricultural practice. The plants can be used both for functional nutrition and for obtaining unique bioactive compounds.

This study was performed within the scope of the scientific project "Biologically active substances of less common fruit plants as the effective means of improving quality of products and raw materials for the functional nutrition" (registration number 0121U109772) financed by Ministry of Education and Science of Ukraine.

The authors declare that they have no competing interests.

\section{References}

Ashakirin, S. N., Tripathy, M., Patil, U. K., \& Majeed, A. B. A. (2017). Chemistry and bioactivity of cinnamaldehyde: A natural molecule of medicinal importance. International Journal of Pharmaceutical Sciences and Research, 8(6), 2333-2340. 
Belge, B., Llovera, M., Comabella, E., Graell, J., \& Lara, I. (2014). Fruit cuticle composition of a melting and a nonmelting peach cultivar. Journal of Agricultural and Food Chemistry, 62, 3488-3495.

Bhimba, B. V., Pushpam, A. C., Arumugam, P., \& Prakash, S. (2012). Phthalate derivatives from the marine fungi Phoma herbarum VB7. International Journal of Biological and Pharmaceutical Research, 3(4), 507-512.

Buschhaus, C., Herz, H., \& Jetter, R. (2007). Chemical composition of the epicuticular and intracuticular wax layers on adaxial sides of Rosa canina leaves. Annals of Botany, 100(6), 1557-1564.

Diab, T. A., Donia, T., \& Saad-Allah, K. M. (2021). Characterization, antioxidant, and cytotoxic effects of some Egyptian wild plant extracts. Beni-Suef University Journal of Basic and Applied Sciences, 10, 13.

Dilika, F., Bremner, P. D., \& Meyer, J. J. M. (2000). Antibacterial activity of linoleic and oleic acids isolated from Helichrysum pedunculatum: Plant used during circumcision rites. Fitoterapia, 71, 450-452.

Ding, S., Zhang, J., Yang, L., Wang, X., Fu, F., Wang, R., Zhang, Q., \& Shan, Y. (2020). Changes in cuticle components and morphology of 'Satsuma' Mandarin (Citrus unshiu) during ambient storage and their potential role on Penicillium digitatum infection. Molecules, 25(2), 412.

Doyle, A. A., \& Stephens, J. C. (2019). A review of cinnamaldehyde and its derivatives as antibacterial agents. Fitoterapia, 139(11), 104405.

Du, H., Wu, J., Li, H., Zhong, P. X., Xu, Y. J., Li, C. H., Ji, K. X., \& Wang, L. S. (2013). Polyphenols and triterpenes from Chaenomeles fruits: Chemical analysis and antioxidant activities assessment. Food Chemistry, 141, 4260-4268.

Fernandes, C. P., Corrêa, A. L., Lobo, J. F. R., Caramel, O. P., de Almeida, F. B., Castro, E. S., Souza, K. F. C. S., Burth, P., Amorim, L. M. F., Santos, M. G., Ferreira, J. L. P., Falcão, D. Q., Carvalho, J. C. T., \& Rocha, L. (2013). Triterpene esters and biological activities from edible fruits of Manilkara subsericea (Mart.) Dubard, Sapotaceae. BioMed Research International, 2013, 280810.

Fernández, V., Guzmán-Delgado, P., Graça, J., Santos, S., \& Gil, L. (2016). Cuticle structure in relation to chemical composition: Re-assessing the prevailing model. Frontiers in Plant Science, 7, 427.

Hao, S., Ma, Y., Zhao, S., Ji, Q., Zhang, K., Yang, M., \& Yao, Y. (2017). McWRI1, a transcription factor of the AP2/SHEN family, regulates the biosynthesis of the cuticular waxes on the apple fruit surface under low temperature. PLoS One, 12(10), e0186996.

Kikowska, M., Włodarczyk, A., Rewers, M., Sliwinska, E., Studzinska-Sroka, E., Witkowska-Banaszczak, E., \& Thiem, B. (2019). Micropropagation of Chaenomeles japonica: A step towards production of polyphenol-rich extracts showing antioxidant and antimicrobial activities. Molecules, 24(7), 1314.

Kosma, D. K., Bourdenx, B., Bernard, A., Parsons, E. P., Lu, S., Joubes, J., \& Jenks, M. A. (2009). The impact of water deficiency on leaf cuticle lipids of Arabidopsis. Plant Physiology, 151(4), 1918-1929.

Lazniewska, J., Macioszek, V., \& Kononowicz, A. (2012). Plant-fungus interface: The role of surface structures in plant resistance and susceptibility to pathogenic fungi. Physiological and Molecular Plant Pathology, 78, 24-30.

Lotfy, M. M., Hassan, H. M., Hetta, M. H., El-Gendy, A. O., \& Mohammed, R. (2018). Di(2-ethylhexyl) phthalate, a major bioactive metabolite with antimicrobial and cytotoxic activity isolated from River Nile derived fungus Aspergillus awamori. Beni-Suef University Journal of Basic and Applied Sciences, 7(3), 263-269.

Lykholat, Y. V, Khromykh, N. O., Lykholat, T. Y., Didur, O. O., Lykholat, O. A., Legostaeva, T. V., Kabar, A. M., Sklyar, T. V., Savosko, V. M., Kovalenko, I. M., Davydov, V. R., Bielyk, Y. V., Volyanik, K. O., Onopa, A. V., Dudkina, K. A., \& Grygoryuk, I. P. (2019). Industrial characteristics and consumer properties of Chaenomeles Lindl. fruits. Ukrainian Joumal of Ecology, 9(3), 132-137.

Lykholat, Y. V., Khromykh, N. O., Didur, O. O, Davydov, V. R., Sklyar, T. V., Drehval, O. A., Vergolyas, M. R., Verholias, O. O., Marenkov, O. M., Nazarenko, M. M., Lavrentieva, K. V., Kurahina, N. V., Lykholat, O. A., Legostaeva, T. V., Zaytseva, I. O., Kabar, A. M., \& Lykholat, T. Y. (2021). Features of the fruit epicuticular waxes of Prunus persica cultivars and hybrids concerning pathogens susceptibility. Ukrainian Journal of Ecology, 11(1), 261-266.

Lykholat, Y. V., Khromykh, N. O., Pirko, Y. V., Alexeyeva, A. A., Pastukhova, N. L., \& Blume, Y. B. (2018). Epicuticular wax composition of leaves of Tilia L. trees as a marker of adaptation to the climatic conditions of the Steppe Dnieper. Cytology and Genetics, 52(5), 323-330.
Martin, L. B., \& Rose, J. K. (2014). There's more than one way to skin a fruit: Formation and functions of fruit cuticles. Journal of Experimental Botany, 65(16), 4639-4651.

Miao, J., Zhao, C., Li, X., Chen, X., Mao, X., Huang, H., Wang, T., \& Gao, W. (2016). Chemical composition and bioactivities of two common Chaenomeles fruits in China: Chaenomeles speciosa and Chaenomeles sinensis. Journal of Food Science, 81, H2049-H2058.

Moskalets, T. Z., Moskalets, V. V., Vovkohon, A. H., Shevchuk, O. A., \& Matviichuk, O. A. (2019). Modem breeding and cultivation of unpopular fruits and berries in Ukraine. Ukrainian Journal of Ecology, 9(3), 180-188.

Rebora, M., Salerno, G., Piersanti, S., Gorb, E., \& Gorb, S. (2020). Role of fruit epicuticular waxes in preventing Bactrocera oleae (Diptera: Tephritidae) attachment in different cultivars of Olea europaea. Insects, 11, 189.

Rios, J. C., Robledo, F., Schreiber, L., Zeisler, V., Lang, E., Carrasco, B., \& Silva, H. (2015). Association between the concentration of n-alkanes and tolerance to cracking in commercial varieties of sweet cherry fruits. Scientia Horticulturae, 197(14), 57-65.

Rumpunen, K. (2002). Chaenomeles: Potential new fruit crop for Northern Europe. In: Janick, J., \& Whipkey, A. (Eds.). Trends in new crops and new uses. ASHS Press, Alexandria. Pp. 385-392.

Tomasi, P., Dyer, J. M., Jenks, M. A., \& Abdel-Haleem, H. (2018). Characterization of leaf cuticular wax classes and constituents in a spring Camelina sativa diversity panel. Industrial Crops and Products, 112, 247-251.

Trivedi, P., Nguyen, N., Hykkerud, A. L., Häggman, H., Martinussen, I., Jaakola, L., \& Karppinen, K. (2019). Developmental and environmental regulation of cuticular wax biosynthesis in fleshy fruits. Frontiers in Plant Science, 10, 431.

Urbanaviciute, I., Liaudanskas, M., Bobinas, C., Šarkinas, A., Rezgiene, A., Viskelis, P. (2020). Japanese quince (Chaenomeles japonica) as a potential source of phenols: Optimization of the extraction parameters and assessment of antiradical and antimicrobial activities. Foods, 9, 1132.

Walters, D., Raynor, L., Mitchell, A., Walker, R., \& Walker, K. (2004). Antifungal activities of four fatty acids against plant pathogenic fungi. Mycopathologia, 157(1), 87-90.

Wang, J., Hao, H., Liu, R., Ma, Q., Xu, J., Chen, F., Cheng, Y., \& Deng, X. (2014). Comparative analysis of surface wax in mature fruits between Satsuma mandarin (Citrus unshiu) and 'Newhall' navel orange (Citrus sinensis) from the perspective of crystal morphology, chemical composition and key gene expression. Food Chemistry, 153, 177-185.

Wu, X., Yin, H., Shi, Z., Chen, Y., Qi, K., Qiao, X., Wang, G., Cao, P., \& Zhang, S. (2018). Chemical composition and crystal morphology of epicuticular wax in mature fruits of 35 Pear (Pyrus spp.) cultivars. Frontiers in Plant Science, 9, 679.

Xianfei, X., Xiaoqiang, C., Shunying, Z., \& Guolin, Z. (2007). Chemical composition and antimicrobial activity of essential oils of Chaenomeles speciosa from China. Food Chemistry, 100(4), 1312-1315.

Xue, D., Zhang, X., Lu, X., Chen, G., \& Chen, Z.-H. (2017). Molecular and evolutionary mechanisms of cuticular wax for plant drought tolerance. Frontiers in Plant Science, 8, 621.

Yang, L., Ahmed, S., Stepp, J. R., Zhao, Y., Zeng, M. J., Pei, S., Xue, D., \& Xu, G. (2015). Cultural uses, ecosystem services, and nutrient profile of flowering quince (Chaenomeles speciosa) in the highlands of Western Yunnan, China. Economic Botany, 69(3), 273-283.

Zhang, S. Y., Han, L. Y., Zhang, H., \& Xin, H. L. (2014). Chaenomeles speciosa: A review of chemistry and pharmacology. Biomedical Reports, 2, 12-18.

Zheng, C. J., Yoo, J. S., Lee, T. G., Cho, H. Y., Kim, Y. H., \& Kim, W. G. (2005). Fatty acids synthesis is a target for antibacterial activity of unsaturated fatty acids. FEBS Letters, 579(23), 5157-5162.

Zheng, X., Wang, H., Zhang, P., Gao, L., Yan, N., Li, P., Liu, X., Du, Y., \& Shen, G. (2018). Chemical composition, antioxidant activity and $\alpha$-glucosidase inhibitory activity of Chaenomeles speciosa from four production areas in China. Molecules, 23(10), 2518.

Zvikas, V., Urbanaviciute, I., Bernotiene, R., Kulakauskiene, D., Morkunaite, U., Balion, Z., Majiene, D., Liaudanskas, M., Viskelis, P., Jekabsone, A., \& Jakstas, V. (2021). Investigation of phenolic composition and anticancer properties of ethanolic extracts of japanese quince leaves. Foods, 10(1), 18. 